\title{
Role of tissue-specific AT-rich DNA sequence-binding proteins in lymphocyte differentiation
}

\author{
Takafumi Yokota • Yuzuru Kanakura
}

Received: 27 April 2014/Revised: 13 May 2014/Accepted: 14 May 2014/Published online: 18 June 2014

(C) The Japanese Society of Hematology 2014

\begin{abstract}
A great many transcription factors, cytokines, and cytokine receptors have been identified as indispensable elements in lymphocyte differentiation, but the molecular mechanism that orchestrates the expression and function of these molecular factors is unknown. The process of lymphocyte differentiation involves both the simultaneous activation of lymphoid-related genes and the inactivation of non-lymphoid lineage-related genes, suggesting that there should be critical molecules that regulate such gene expression in both temporal and spatial dimensions. Recent studies of chromatin-remodeling proteins shed light on this complex process. In particular, special AT-rich sequence-binding protein 1 has been studied extensively. In this article, we review the wealth of information characterizing this protein.
\end{abstract}

Keywords ARID - AT-rich sequence-binding proteins . Epigenetics · Lymphopoiesis · SATB1

\section{Introduction}

Lymphocytes are generated from multipotent hematopoietic stem cells (HSCs). The process of lymphocyte production represents a paradigm for cell differentiation, in which signaling pathways and transcription factors coordinately induce the step-wise maturation of HSCs and

T. Yokota $(\bowtie) \cdot$ Y. Kanakura $(\bowtie)$

Department of Hematology and Oncology, Osaka University

Graduate School of Medicine, 2-2 Yamada-oka, Suita,

Osaka 565-0871, Japan

e-mail: yokotat@bldon.med.osaka-u.ac.jp

Y. Kanakura

e-mail: kanakura@bldon.med.osaka-u.ac.jp multipotent progenitors into specialized effector cells [13]. However, the expression of lymphoid lineage-specific genes is determined by the combination of signaling pathways and transcription factors and also by epigenetic mechanisms such as DNA methylation, histone modification, chromatin structure remodeling and small RNA [4-8].

The organization of chromatin structure that creates accessibility to target genes is important in the regulation of cell differentiation $[9,10]$. A global genome organizer, such as CCCTC-binding factor, regulates chromatin topology, forming transcriptionally repressive and permissive compartments [11, 12]. Recent reports have revealed the mechanisms by which genetic factors and epigenetic modifications complementarily regulate $\mathrm{B}$ lymphoid-lineage specification and commitment $[13,14]$. In this review, we discuss the function of chromatinremodeling proteins in lymphocyte differentiation, particularly focusing on those that bind AT-rich sequences.

\section{Proteins with AT-rich sequence-binding properties}

The nuclear matrix was originally defined as residual nuclear structure following extensive treatment with salts, detergents and enzymes, which provides a frame to maintain the spherical shape of the nucleus [15]. Subsequent studies suggested that the nuclear matrix is indispensable to organize higher-order chromatin loops, and that DNA sequences that bind specifically to the nuclear matrix are critically involved in this loop formation [16, 17]. Such DNA sequences are named matrix attachment regions (MARs) or scaffold-associated regions.

AT-rich DNA sequences are involved in DNA replication and RNA synthesis by acting as targets of nuclear receptors, transcription factors, and DNA/RNA 


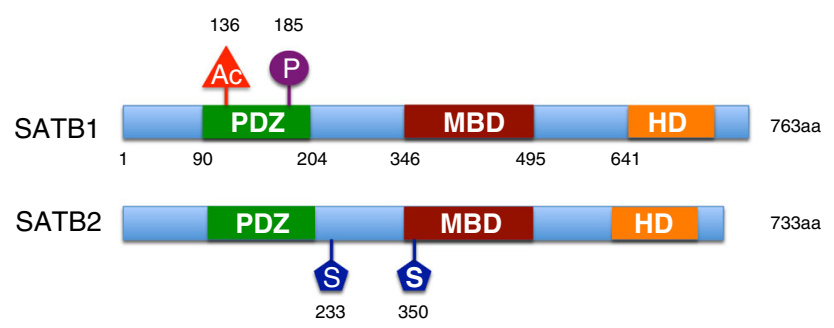

Bright/ARID3a

ARID

593aа

Fig. 1 Schematic representation of the domain structure of murine SATB1, SATB2 and Bright/ARID3a. SATB1 and SATB2 have similar structure which consists of a PDZ-like domain (PDZ), a MAR-binding domain (MBD) and a homeodomain (HD). The PDZ domain is important not only for the interaction with partner proteins but also for the homodimerization. The MBD and HD are indispensable for recognition of MARs and specific binding to target genes. The phosphorylation site $(P)$ and the acetylation site (Ac) in the PDZ domain of SATB1 and the sumoylation sites $(S)$ in SATB2 are depicted. The ARID family comprises 15 members which are categorized into 7 subfamilies. The ARID3 subfamily differs from other ARID members at the $\mathrm{N}$ and $\mathrm{C}$ terminals of ARID which form alpha helices in the protein structure. These alpha helices are termed the extended ARID $(E)$. The C-terminal extended ARID is important to recognize target genes. Among the ARID family proteins, only the Bright/ARID3a is known to play roles in lymphopoiesis

polymerases [18-20]. In particular, AT-rich sequences in MARs contribute to the formation of a higher-order structure of chromatin and generate functional chromatin loops, in which long-range interactions among enhancers, promoters, and coding sequences are enabled [21-23]. This chromatin-remodeling process involves MAR-binding proteins that bind the AT-rich DNA sequences.

To date, two MAR-binding protein groups have been found to play roles in the lymphoid lineage; one group is the special AT-rich sequence-binding (SATB) family that recognizes the ATC sequence context, and the other is the AT-rich interaction domain (ARID) family (Fig. 1). The former consists of two proteins: SATB1 and SATB2 [2427]. The latter comprises 15 ARID-containing proteins in mouse and human, which can be classified into seven distinct subfamilies-ARID1 through ARID5, JumonjiARID (JARID) 1, and JARID2 [28]. Among the 15 ARIDcontaining proteins, ARID3a, also known as B cell regulator of immunoglobulin (Ig) heavy chain (IgH) transcription (Bright), is required for the development of HSCs and B lymphocytes [29].

\section{SATB1 function in lymphopoiesis}

SATB1 was originally identified by Kowhi-Shigematsu's group as a binding partner using a synthetic MAR probe, which was created by concatemerizing the MAR sequence located at the $3^{\prime}$ end of the $\operatorname{IgH}$ gene enhancer
[24]. Although the brain and testis express a minute amount of SATB1 transcripts, SATB1 is predominantly expressed in the thymus [24]. Thus, SATB1 is the first known MAR-binding protein whose function is likely tissue-specific.

A subsequent study by Kowhi-Shigematsu's group revealed that SATB1 expression is highly associated with thymocyte differentiation [30]. SATB1 deficiency causes severe immunodeficiency and multiple defects in T-lineage development. Immature $\mathrm{CD} 3^{-} \mathrm{CD} 4^{-} \mathrm{CD} 8^{-}$triple-negative subset of thymocytes is greatly reduced in the thymus of SATB1-deficient mice. Even more serious problems in cell differentiation were observed at the $\mathrm{CD} 4^{+} \mathrm{CD} 8^{+}$double-positive stage. The SATB1-deficient $\mathrm{CD} 4^{+} \mathrm{CD}^{+}{ }^{+}$double-positive thymocytes almost completely lost the differentiation potential to $\mathrm{CD}^{+}$or $\mathrm{CD}^{+}$single-positive thymocytes [30]. These phenotypes correlate with the expression levels of SATB1 in thymocytes. We previously observed that $S A T B 1$ expression is remarkably upregulated at the $\mathrm{CD} 4^{+} \mathrm{CD} 8^{+}$doublepositive stage and remains very high through the maturation to single-positive cells (T.Y. unpublished observation). Under the SATB1-deficient condition, numerous genes, including $I L 2 R \alpha$ and $I L 7 R \alpha$, remain aberrantly transcribed in the $\mathrm{CD} 4^{+} \mathrm{CD} 8^{+}$double-positive thymocytes [30]. Thus, SATB1 is thought to regulate the temporal and spatial expression of various genes during the early stages of $\mathrm{T}$ cell development.

SATB1 is also involved in the late stages of T-lineage differentiation. Interestingly, the downregulation of $S A T B 1$ expression is necessary for the generation and maintenance of $\mathrm{CD}^{+}{ }^{+} \mathrm{CD} 25^{+}$regulatory $\mathrm{T}$ cells (Tregs) [31]. In this process, the X-linked forkhead transcription factor, Foxp3, plays critical roles; Foxp3 directly represses the SATB1 locus by binding to the transcriptional promoter site and the genomic locus, and it indirectly inhibits $S A T B 1$ expression through the induction of microRNAs that bind to the SATB $13^{\prime}$ untranslated region. The Tregs lose their suppressive function and acquire the effector $\mathrm{T}$ cell phenotypes, such as interferon gamma $(I F N-\gamma)$ and interleukin 5 (IL5) expression via ectopic expression of SATB1 [31]. Thus, suppression of SATB1 expression is thought to be indispensable for the functional integrity of Tregs.

Compared with the T-lineage, the B-lineage appears to be less sensitive to SATB1 ablation. Nevertheless, while the B cell population in SATB1-deficient mice appears to be unaffected in terms of the expression of B220, IgM, and $\mathrm{IgD}$, the absolute number of $\mathrm{B}$ lymphocytes significantly decreases [30]. In addition, our group identified increased SATB1 expression in lymphoid-primed multipotent progenitors and early lymphoid progenitors, both of which have high potential to produce B- and T-lineage cells in vivo [32]. These observations signify SATB1 activity in 
the very early stages of B-lineage differentiation. In fact, HSCs transduced with a SATB1-overexpressing vector efficiently produce B-lineage cells in stromal cell co-cultures. In addition, the production of natural killer lymphocytes is enhanced by SATB1 overexpression. Of note, those SATB1-overexpressing HSCs are less capable of producing myeloid cells and dendritic cells in culture than control HSCs [32].

A recent report also determined the significance of SATB1 expression in HSCs [33]. The SATB1-deficient HSCs were found to be less quiescent and more prone to differentiate, preferentially to myeloid-erythroid lineages [33]. Our group also detected low levels of SATB1 expression in HSCs, in which levels remarkably declined in myeloid-biased aged HSCs [32]. Thus, SATB1 expression is likely important for HSCs to maintain self-renewal capacity and differentiation potential. However, we must stress here that higher SATB1 expression does not necessarily improve HSC function. Our group observed that SATB1-overexpressing HSCs effectively generate both T and B lymphocytes for a short term after transplantation to lethally irradiated mice, but the HSCs fail to establish longterm reconstitution ([32] and T.Y unpublished observation). Taken together, we presume that a low level of SATB1 protein is necessary to inhibit spontaneous differentiation of HSCs toward myeloid-erythroid cells and to maintain HSC function, but a high level of SATB1 strongly induces the lymphoid differentiation program in HSCs (summarized in Fig. 2).

\section{SATB1-targeted genes in lymphocyte differentiation}

As described in "SATB1 function in lymphopoiesis", SATB1 exhibits lineage and differentiation stage-specific function in lymphopoiesis. These specificities are presumably due to a discrete set of SATB1 target genes in each lineage or differentiation stage.

In SATB1-deficient thymocytes, expression levels of up to $2 \%$ of the total genes, including CD25/IL2Ra, IL7Ra, and $c-M y c$, are greatly dysregulated [30]. Overexpression of CD25/IL2Ra has also been confirmed by in vitro experiments, in which SATB1-deficient HSCs were cocultured with OP9-delta1 stromal cells [32]. In human T cell development, SATB1 binds directly to MARs in the CD8 gene [34]. In the later stage of T cell differentiation, SATB1 controls multiple IL4 target genes and establishes effector T cell function by inducing $I L A, I L 5, I F N-\gamma$, and IL17a gene expression [31, 35].

In terms of primitive hematopoietic progenitors, aberrant enhancement of $c-M y c$ and $N u m b$, encoding a repressor of the Notch signaling pathway, was observed in SATB1-deficient HSCs, and both appear to increase commitment to myeloid-erythroid lineages of SATB1-deficient HSCs [33]. In contrast, SATB1 overexpression induces the expression of various lymphoid-related genes in HSCs, such as Ragl, CD8a, Blink, ILI7Ra, and ILAR, whereas it represses GATA5, which encodes an essential transcription factor of erythroid lineage, and Csf $3 R$, encoding the G-CSF receptor [32]. Irrespective of whether these genes are direct
Fig. 2 Influence of AT-rich sequence-binding proteins on lymphocyte differentiation. Commitment of mesodermal progenitors (Mesoderm) to HSCs, self-renewal (curved arrow) and subsequent differentiation (straight gray arrows) through intermediate stages to effector cells are illustrated. Blue arrows indicate positive regulation whereas blunt ended red lines suggest that the influence is inhibitory. Dashed arrows indicate possible relations, which remain to be elucidated. LMPP, lymphoidprimed multipotent progenitor; $E L P$, early lymphoid progenitor; $C L P$, common lymphoid progenitor; $E T P$, early thymic progenitor; $G M P$, granulocyte macrophage progenitor; and MegEP, megakaryocyte erythrocyte progenitor

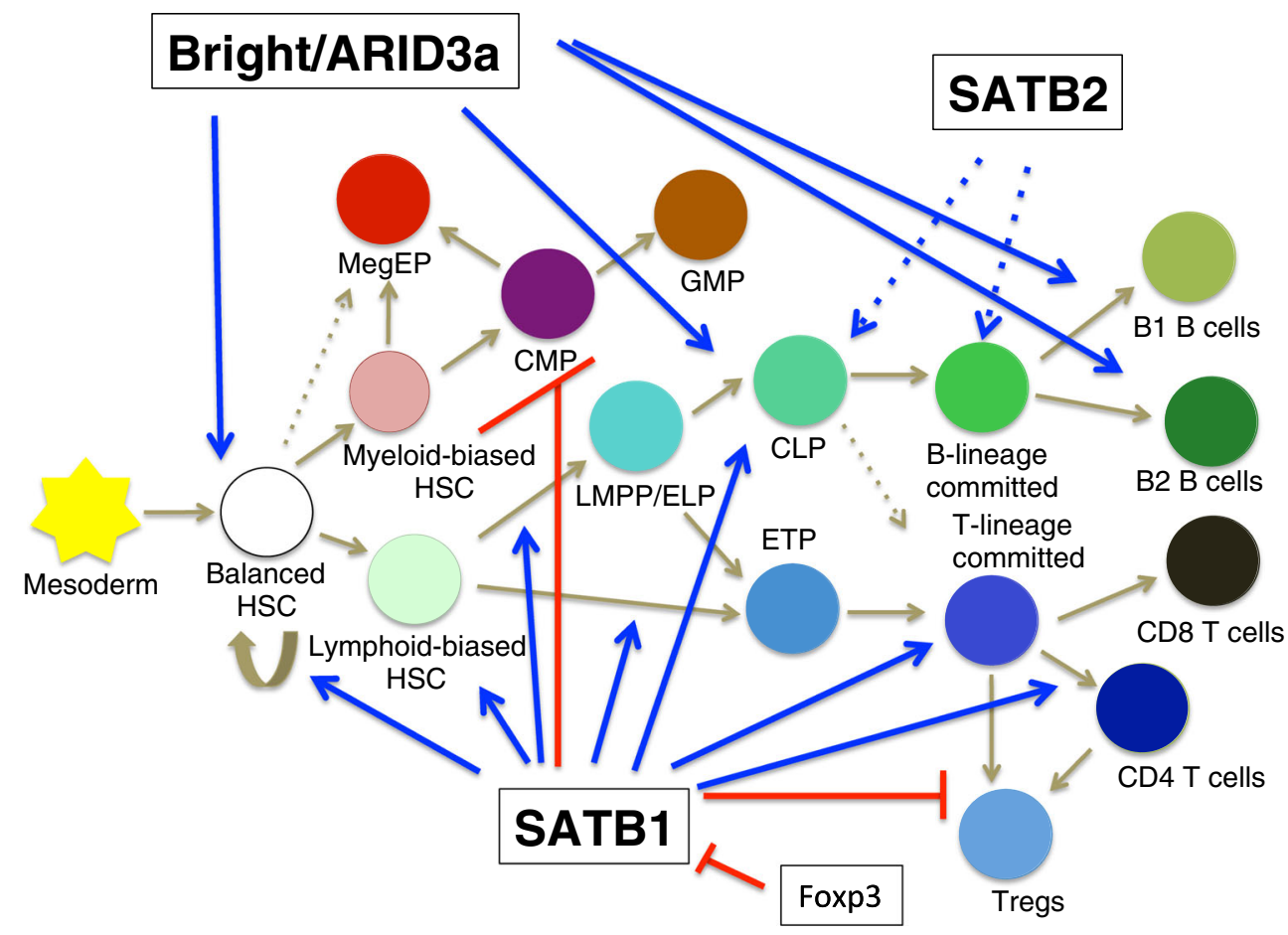


or indirect targets of SATB1, the net effect of such changes determines the fate of HSCs. Some differences observed experimentally in expression of SATB1 target genes that are influenced by a loss-of function or a gain-of function likely reflect the dose-dependent function of SATB1 proteins.

Notably, in embryonic stem cells, SATB1 deficiency impairs their differentiation potential and augments expression of Nanog, Klf4, and Tbx3, which function as the pluripotency determinants [36]. Furthermore, during brain development, SATB1 regulates multiple genes such as Fos, Fosb, Egrl, Egr2, Arc, and Bdnf that serve as critical neuronal genes to organize synaptic plasticity [37]. Thus, SATB1 targets genes in a context-dependent manner.

\section{SATB1-associated molecules}

In this section, we describe the basic characteristics of SATB1 as a transcription-regulating protein. SATB1 forms multimers in the nucleus by homophilic interaction through its PDZ-like domain [38]. The multimeric SATB1 proteins are distributed in the euchromatin of thymocyte nuclei by forming a three-dimensional cage-like structure surrounding dense chromatin regions [39]. SATB1 also has a MARbinding domain and an atypical homeodomain [40, 41], which presumably enable the protein to recruit its specific targets onto the nuclear matrix/scaffold platform (Fig. 3).

Association with various proteins affords diverse functions to SATB1. Notani et al. [42] showed that SATB1 interacts with $\beta$-catenin, which acts as a transcriptional regulator mediating Wnt signaling. This SATB1/ $\beta$-catenin interaction coordinately induces GATA3 expression, resulting in the determination of commitment to the $\mathrm{CD} 4^{+}$ helper type $2 \mathrm{~T}\left(\mathrm{~T}_{\mathrm{H}} 2\right)$ cell lineage. Upon the activation of $\mathrm{T}_{\mathrm{H}} 2$ cells, SATB1 forms active chromatin structures at the $\mathrm{T}_{\mathrm{H}} 2$ cytokine locus of mouse chromosome 11 , where $I l 4$, Il5 and $I l 13$ genes are clustered, in concert with GATA3, STAT6, c-Maf and RNA polymerase II [43]. SATB1 also interacts with the promyelocytic leukemia body (PML) [44]. The SATB1/PML complex induces higher-order chromatin-loop structures in the major histocompatibility complex (MHC) Class I locus and regulates the expression profile of MHC Class I under inflammation stimuli.

Furthermore, SATB1 associated with epigenetic modifiers. SATB1 directly binds to several histone modification enzymes and chromatin-remodeling factors. In thymocytes, SATB1 recruits the nucleosome remodeling and histone deacetylase (HDAC) complex to the IL2Ra gene and represses its expression [45]. Among the components of the nucleosome remodeling and HDAC complex, SATB1 directly interacts with HDAC1, HDAC-associated corepressor metastasis-associated protein-2 (MTA-2), and

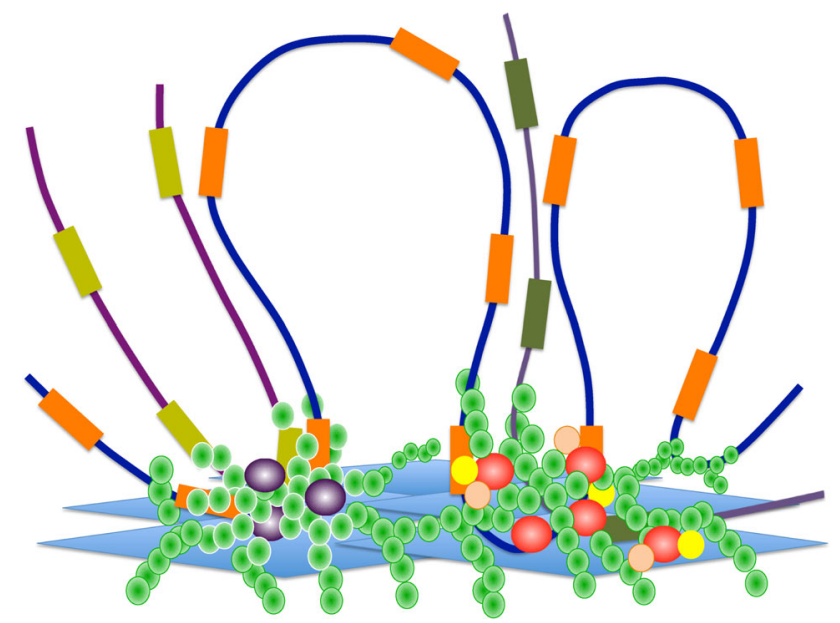

Fig. 3 SATB1 constructs the chromatin-loop structure for global gene regulation. This cartoon depicts the putative mechanism of SATB1 (green ovals) in regulating expression of multiple genes (orange, light green and dark green rectangles) located in different chromatins (blue, light purple and gray lines) through the interaction with histone modifiers, such as HDAC1 (purple ovals) and $\mathrm{CBF} / \mathrm{p} 300$ (red ovals). SATB1 also recruits diverse transcription factors (yellow and orange circles), and thereby organizes transcriptional complexes on the target genes. SATB1 protein is thought to form transcription machinery in association with the nuclear matrix structure (sky blue rhombuses), but the biochemical characteristics of "nuclear matrix" remain to be elucidated

ATP-dependent remodeling enzyme Mi-2. The interaction between HDAC1 and SATB1 is functionally important for human $\mathrm{T}$ cell development. This importance is clearly evident because the retroviral transactivator protein produced by human immunodeficiency virus type 1 displaces HDAC1 by directly binding to SATB1, resulting in aberrant expression of $I L 2 R$ [46]. Such mechanisms inhibiting SATB1 function presumably are involved in virus-induced immunodeficiency.

In addition to association with co-repressors, SATB1 also interacts with transcriptional co-activator proteins such as $\mathrm{CBF} / \mathrm{p} 300$ [47]. Interestingly, depending on the SATB1 phosphorylation status, SATB1 switches its interacting molecules and completely reverses regulation of gene expression [48]. HDAC1 is recruited to target genes by phosphorylated SATB1, whereas $\mathrm{CBF} / \mathrm{p} 300$ is recruited by dephosphorylated SATB1 to sustain transcriptionally active histone modifications such as H3K9/K14 acetylation. The dephosphorylated SATB1 preferentially associates with $\mathrm{CBF} / \mathrm{p} 300$-associated factor acetyltransferase and is likely to be acetylated at the 136th position lysine (see Fig. 1). This acetylation abolishes the DNA-binding activity of SATB1. This mechanism suggests that SATB1 can reciprocally regulate the expression of target genes in response to cell-activating stimuli. Therefore, SATB1 action appears to be protean and context-dependent (Fig. 3). 


\section{SATB1 and hematopoietic malignancies}

As a global regulator of gene expression, SATB1 is involved in the occurrence of hematopoietic malignancies. High expression of SATB1 is implicated in aggressive characteristics of breast cancer cells [49, 50]. Furthermore, its aberrant expression was reported in various types of cancers, including laryngeal squamous cell carcinoma, endometrioid endometrial cancer, hepatocellular carcinoma, and gastric cancer [51]. These reports demonstrated that high SATB1 expression is correlated with high metastatic potential and poor prognosis. Contrary to observations in epithelial tumors, SATB1 appears to suppress the progression of leukemia and lymphoma.

Hypomorphic mutation in a distal enhancer of the Sfpil gene, which encodes transcription factor PU.1, causes acute myeloid leukemia (AML) in mice [52]. This mutation is likely involved in human leukemogenesis, because a single nucleotide polymorphism in this region is frequently observed in human AML [53]. SATB1 binds to this distal enhancer of Sfpil. The single nucleotide polymorphism specifically influences SATB1 binding, resulting in reduced PU.1 expression in myeloid progenitor cells [54]. Thus, it is evident that SATB1 dysfunction is associated with a subset of human AML patients.

$\mathrm{X}$-chromosome inactivation is necessary for mammals to compensate for the difference of X-chromosome numbers between males and females [55]. Noncoding Xist RNA plays an essential role in the initiation of X-chromosome silencing, and this silencing process is restricted to a developmental context in early embryos and hematopoietic progenitors [56]. Concomitant with the reduction of Xist expression, inactivation of the X-chromosome is transiently released in early lymphoid progenitors. Thereafter, the Xist-mediated silencing revives along with their physiological differentiation to mature $\mathrm{B}$ or $\mathrm{T}$ cells [56]. Ectopic Xist expression can induce cell death in vivo in normal lymphoid progenitors and also in lymphoma cells, but a small subset of the Xist-induced lymphoma cells become resistant to Xist-mediated cell death during in vitro culture. Agrelo et al. [57] performed genome-wide expression profiling of Xist-responsive and Xist-resistant tumors and identified SATB1 as an X-chromosome silencing factor associated with Xist in their experimental model. Indeed, viral-induced SATBI expression restored the silencing function of Xist in the resistant tumor cells and reduced their survival upon Xist induction. Although the physiological significance of SATB1 protein in the $\mathrm{X}$-chromosome inactivation is still contentious ([58] and personal communication with Dr. Terumi Kohwi-Shigematsu), the results above suggest that modulation of SATB1 and Xist interaction may offer a new therapeutic approach to lymphoid malignancies.

\section{SATB2 function in lymphopoiesis}

SATB2 is a MAR-binding protein closely related to SATB1. It was originally identified as a binding protein of the MAR flanking the intragenic $I g h$ enhancer in pre-B cells [26]. Sequence analysis of SATB2 revealed high structural similarity with SATB1, determined by more than $80 \%$ identity in the MAR domain and homeodomain (Fig. 1). Accordingly, SATB2 interacts with HDAC1 and MTA-2 and plays a role in integrating genetic and epigenetic signals, as SATB1 does [59]. On the other hand, SATB2 differs from SATB1 in the conjugation of small ubiquitin-related modifiers, which regulate the activation potential of SATB2 on its target genes. Further, the sumoylation affects the localization of SATB2 by targeting the protein to the nuclear periphery [26]. In embryonic stem cells, SATB2 binds to the enhancer of Nanog, as SATB1 does. However, the function of SATB1 and SATB2 on Nanog expression is mutually antagonizing, and SATB2 contributes to maintain reprogramming potential in embryonic stem cells [36].

While SATB1 function is significantly involved in the lymphoid lineage, the physiological importance of SATB2 has been well documented for the development of other lineages, particularly osteoblasts and neuronal cells [6062]. Using a human disease genomics approach, SATB2 was identified as a cleft palate-related gene, and its mutation causes multiple abnormalities, including craniofacial dysmorphism, mental retardation, and osteoporosis [6365]. Unfortunately, there is little information about the phenotype of the human immune system for those SATB2 mutants. SATB2 expression is predominantly pre-B cellspecific among the lymphoid lineage [26]. Our group has also observed a remarkable increase in the ratio of SATB2/ $S A T B 1$ expression levels when common lymphoid progenitors differentiate to pre-B cells. Taken together, the significance of SATB2 function in B-lymphopoiesis warrants further exploration.

\section{Bright/ARID3a function in lymphopoiesis}

Bright/ARID3a is the founding member of the ARID family proteins. Like SATB1 and SATB2, this protein was originally identified as a binding protein of the MAR on Igh [66]. While the expression and function of SATB1 are highly specific to the T-lineage, those of Bright/ARID3a are rather restricted to the B-lineage. In Bright/ARID3adeficient mice, B-lineage development, including both B1 and B2 lineages, is significantly compromised, whereas the population of T-lineage cells is preserved [29, 67, 68].

Bright/ARID3a functions in HSCs and in even more primitive pluripotent stem cells. The majority of Bright/ 
ARID3a-deficient mice die between the E11.5 and E13.5 stages, because of hematopoietic system developmental failure [29]. The frequency and absolute number of HSCs in the fetal livers of such deficient mice and in the adult bone marrows of the rare survivors are significantly reduced, suggesting an indispensable role of Bright/ ARID3a in the development and/or maintenance of HSCs. Intriguingly, the repression of Bright/ARID3a spontaneously converts adult somatic cells to pluripotent cells [69]. Three experimental models using silencing hairpin RNA, dominant-negative Bright/ARID3a transgenic mice, or knockout mice independently confirmed this phenomenon. When Bright/ARID3a is inhibited, pluripotent-associated transcription factors such as Nanog and Sox 2 are induced. A recent report has also shown that Bright/ARID3a deficiency enhances reprogramming of mouse embryonic fibroblasts induced by four standard factors: Oct4, Sox2, Klf, and c-Myc [70], and the Bright/ARID3a deficiency even spontaneously induces pluripotency without those four factors [71]. Bright/ARID3a directly binds to and represses the enhancer regions of Oct4, Sox2, and Nanog in the mouse genome; thus, the protein may contribute to maintaining whole genome integrity in several somatic cell types.

Among the AT-rich sequence-binding proteins introduced in this review, Bright/ARID3a seems to be most clearly associated with human lymphoid neoplasm. Overexpression of this protein correlates with poor prognosis and increased progression of human diffuse large B cell lymphoma [72]. In mice, its ectopic overexpression converts embryonic fibroblasts to tumor cells, bypassing natural or Ras-induced cellular senescence [73]. However, while B lineage-specific overexpression of Bright/ARID3a in mice perturbed the normal development of immature $\mathrm{B}$ cells and caused autoimmune responses, the overexpression did not induce lymphoid neoplasm ([74] and personal communication with Dr. Carol Webb). Therefore, the mechanism clarifying the possible role of Bright/ARID3a as a proto-oncogene remains to be determined.

\section{Concluding remarks}

Recent progress has contributed to our understanding of how genetic and epigenetic mechanisms complementarily regulate gene expression. As an epigenetic mechanism, appropriate chromatin remodeling is necessary for various regulatory factors to access their target genes and assemble transcription machinery. The lymphoid lineagerelated chromatin-remodeling proteins, including SATB1 and Bright/ARID3a, are indispensable for lymphocyte differentiation, even in the very early stages. Furthermore, accumulating evidence introduced in this review supports the idea that these proteins are involved in a wide range of cellular processes, including stem cell development. The specific environmental cues regulating the expression and function of these chromatin remodelers remain to be elucidated. We believe that future studies on this topic will inform epigenetic approaches to control immune response, immuno-senescence, and malignant transformation.

Acknowledgments We thank Drs. Kiyoe Ura (Osaka University), Paul Kincade (Oklahoma Medical Research Foundation), Carol Webb (Oklahoma Medical Research Foundation) and Terumi Kohwi-Shigematsu (University of California) for critical reading of the manuscript.

Conflict of interest The authors declare that they have no conflict of interest.

\section{References}

1. Rothenberg EV, Moore JE, Yui MA. Launching the T-cell-lineage developmental programme. Nat Rev Immunol. 2008;8:9-21.

2. Busslinger M. Transcriptional control of early B cell development. Annu Rev Immunol. 2004;22:55-79.

3. Mandel EM, Grosschedl R. Transcription control of early B cell differentiation. Curr Opin Immunol. 2010;22:161-7.

4. Sashida G, Iwama A. Epigenetic regulation of hematopoiesis. Int J Hematol. 2012;96:405-12.

5. Su IH, Tarakhovsky A. Epigenetic control of B cell differentiation. Semin Immunol. 2005;17:167-72.

6. Matthews AG, Oettinger MA. RAG: a recombinase diversified. Nat Immunol. 2009;10:817-21.

7. Georgopoulos K. Haematopoietic cell-fate decisions, chromatin regulation and ikaros. Nat Rev Immunol. 2002;2:162-74.

8. Okuyama K, Ogata J, Yamakawa N, Chanda B, Kotani A. Small RNA as a regulator of hematopoietic development, immune response in infection and tumorigenesis. Int $\mathrm{J}$ Hematol. 2014;99(5):553-60.

9. Lin YC, Murre C. Nuclear location and the control of developmental progression. Curr Opin Genet Dev. 2012.

10. Schneider R, Grosschedl R. Dynamics and interplay of nuclear architecture, genome organization, and gene expression. Genes Dev. 2007;21:3027-43.

11. Phillips JE, Corces VG. CTCF: master weaver of the genome. Cell. 2009;137:1194-211.

12. Dixon JR, Selvaraj S, Yue F, Kim A, Li Y, Shen Y, Hu M, Liu JS, Ren B. Topological domains in mammalian genomes identified by analysis of chromatin interactions. Nature. 2012;485:376-80.

13. Lin YC, Benner C, Mansson R, Heinz S, Miyazaki K, Miyazaki M, Chandra V, Bossen C, Glass CK, Murre C. Global changes in the nuclear positioning of genes and intra- and inter-domain genomic interactions that orchestrate B cell fate. Nat Immunol. 2012;13:1196-204.

14. Yokota T, Sudo T, Ishibashi T, Doi Y, Ichii M, Orirani K, Kanakura Y. Complementary regulation of early B-lymphoid differentiation by genetic and epigenetic mechanisms. Int $\mathbf{J}$ Hematol. 2013;98:382-9.

15. Berezney R. Coffey DS: identification of a nuclear protein matrix. Biochem Biophys Res Commun. 1974;60:1410-7.

16. Mirkovitch J, Mirault ME, Laemmli UK. Organization of the higher-order chromatin loop: specific DNA attachment sites on nuclear scaffold. Cell. 1984;39:223-32. 
17. Wang TY, Han ZM, Chai YR, Zhang JH. A mini review of MARbinding proteins. Mol Biol Rep. 2010;37:3553-60.

18. Bell SP, Dutta A. DNA replication in eukaryotic cells. Annu Rev Biochem. 2002;71:333-74.

19. Juven-Gershon T, Kadonaga JT. Regulation of gene expression via the core promoter and the basal transcriptional machinery. Dev Biol. 2010;339:225-9.

20. Rajewska M, Wegrzyn K, Konieczny I. AT-rich region and repeated sequences - the essential elements of replication origins of bacterial replicons. FEMS Microbiol Rev. 2012;36:408-34.

21. Cockerill PN, Garrard WT. Chromosomal loop anchorage of the kappa immunoglobulin gene occurs next to the enhancer in a region containing topoisomerase II sites. Cell. 1986;44:273-82.

22. Gasser SM, Laemmli UK. Cohabitation of scaffold binding regions with upstream/enhancer elements of three developmentally regulated genes of D. melanogaster. Cell. 1986;46:521-30.

23. von Kries JP, Buhrmester H, Stratling WH. A matrix/scaffold attachment region binding protein: identification, purification, and mode of binding. Cell. 1991;64:123-35.

24. Dickinson LA, Joh T, Kohwi Y, Kohwi-Shigematsu T. A tissuespecific MAR/SAR DNA-binding protein with unusual binding site recognition. Cell. 1992;70:631-45.

25. Kohwi-Shigematsu T, Maass K, Bode J. A thymocyte factor SATB1 suppresses transcription of stably integrated matrixattachment region-linked reporter genes. Biochemistry. 1997; 36:12005-10

26. Dobreva G, Dambacher J, Grosschedl R. SUMO modification of a novel MAR-binding protein, SATB2, modulates immunoglobulin mu gene expression. Genes Dev. 2003;17:3048-61.

27. Britanova O, Akopov S, Lukyanov S, Gruss P, Tarabykin V. Novel transcription factor SATB2 interacts with matrix attachment region DNA elements in a tissue-specific manner and demonstrates cell-type-dependent expression in the developing mouse CNS. Eur J Neurosci. 2005;21:658-68.

28. Wilsker D, Probst L, Wain HM, Maltais L, Tucker PW, Moran E. Nomenclature of the ARID family of DNA-binding proteins. Genomics. 2005;86:242-51.

29. Webb CF, Bryant J, Popowski M, Allred L, Kim D, Harriss J, Schmidt C, Miner CA, Rose K, Cheng HL, Griffin C, Tucker PW. The ARID family transcription factor bright is required for both hematopoietic stem cell and B lineage development. Mol Cell Biol. 2011;31:1041-53.

30. Alvarez JD, Yasui DH, Niida H, Joh T, Loh DY, Kohwi-Shigematsu T. The MAR-binding protein SATB1 orchestrates temporal and spatial expression of multiple genes during T-cell development. Genes Dev. 2000;14:521-35.

31. Beyer M, Thabet Y, Muller RU, Sadlon T, Classen S, Lahl K, Basu S, Zhou X, Bailey-Bucktrout SL, Krebs W, Schonfeld EA, Bottcher J, Golovina T, Mayer CT, Hofmann A, Sommer D, Debey-Pascher S, Endl E, Limmer A, Hippen KL, Blazar BR, Balderas R, Quast T, Waha A, Mayer G, Famulok M, Knolle PA, Wickenhauser C, Kolanus W, Schermer B, Bluestone JA, Barry SC, Sparwasser T, Riley JL, Schultze JL. Repression of the genome organizer SATB1 in regulatory $\mathrm{T}$ cells is required for suppressive function and inhibition of effector differentiation. Nat Immunol. 2011;12:898-907.

32. Satoh Y, Yokota T, Sudo T, Kondo M, Lai A, Kincade PW, Kouro T, Iida R, Kokame K, Miyata T, Habuchi Y, Matsui K, Tanaka H, Matsumura I, Oritani K, Kohwi-Shigematsu T, Kanakura Y. The SATB1 protein directs hematopoietic stem cell differentiation toward lymphoid lineages. Immunity. 2013;38:1105-15.

33. Will B, Vogler TO, Bartholdy B, Garrett-Bakelman F, Mayer J, Barreyro L, Pandolfi A, Todorova TI, Okoye-Okafor UC, Stanley RF, Bhagat TD, Verma A, Figueroa ME, Melnick A, Roth M, Steidl U. SATB1 regulates the self-renewal of hematopoietic stem cells by promoting quiescence and repressing differentiation commitment. Nat Immunol. 2013;14:437-45.

34. Kieffer LJ, Greally JM, Landres I, Nag S, Nakajima Y, KohwiShigematsu T, Kavathas PB. Identification of a candidate regulatory region in the human $\mathrm{CD} 8$ gene complex by colocalization of DNase I hypersensitive sites and matrix attachment regions which bind SATB1 and GATA-3. J Immunol. 2002; 168:3915-22.

35. Ahlfors H, Limaye A, Elo LL, Tuomela S, Burute M, Gottimukkala KV, Notani D, Rasool O, Galande S, Lahesmaa R. SATB1 dictates expression of multiple genes including IL-5 involved in human $\mathrm{T}$ helper cell differentiation. Blood. 2010;116:1443-53.

36. Savarese F, Davila A, Nechanitzky R, De La Rosa-Velazquez I, Pereira CF, Engelke R, Takahashi K, Jenuwein T, Kohwi-Shigematsu T, Fisher AG, Grosschedl R. SATB1 and SATB2 regulate embryonic stem cell differentiation and Nanog expression. Genes Dev. 2009;23:2625-38.

37. Balamotis MA, Tamberg N, Woo YJ, Li J, Davy B, KohwiShigematsu T, Kohwi Y. SATB1 ablation alters temporal expression of immediate early genes and reduces dendritic spine density during postnatal brain development. Mol Cell Biol. 2011;32:333-47.

38. Galande S, Dickinson LA, Mian IS, Sikorska M, Kohwi-Shigematsu T. SATB1 cleavage by caspase 6 disrupts PDZ domainmediated dimerization, causing detachment from chromatin early in T-cell apoptosis. Mol Cell Biol. 2001;21:5591-604.

39. Cai S, Han HJ, Kohwi-Shigematsu T. Tissue-specific nuclear architecture and gene expression regulated by SATB1. Nat Genet. 2003;34:42-51.

40. Nakagomi K, Kohwi Y, Dickinson LA, Kohwi-Shigematsu T. A novel DNA-binding motif in the nuclear matrix attachment DNAbinding protein SATB1. Mol Cell Biol. 1994;14:1852-60.

41. Dickinson LA, Dickinson CD, Kohwi-Shigematsu T. An atypical homeodomain in $S A T B 1$ promotes specific recognition of the key structural element in a matrix attachment region. J Biol Chem. 1997;272:11463-70.

42. Notani D, Gottimukkala KP, Jayani RS, Limaye AS, Damle MV, Mehta S, Purbey PK, Joseph J, Galande S. Global regulator SATB1 recruits beta-catenin and regulates $\mathrm{T}(\mathrm{H}) 2$ differentiation in Wnt-dependent manner. PLoS Biol. 2010;8:e1000296.

43. Cai S, Lee CC, Kohwi-Shigematsu T. SATB1 packages densely looped, transcriptionally active chromatin for coordinated expression of cytokine genes. Nat Genet. 2006;38:1278-88.

44. Kumar PP, Bischof O, Purbey PK, Notani D, Urlaub H, Dejean A, Galande S. Functional interaction between PML and SATB1 regulates chromatin-loop architecture and transcription of the MHC class I locus. Nat Cell Biol. 2007;9:45-56.

45. Yasui D, Miyano M, Cai S, Varga-Weisz P, Kohwi-Shigematsu T. SATB1 targets chromatin remodelling to regulate genes over long distances. Nature. 2002;419:641-5.

46. Kumar PP, Purbey PK, Ravi DS, Mitra D, Galande S. Displacement of $S A T B 1$-bound histone deacetylase 1 corepressor by the human immunodeficiency virus type 1 transactivator induces expression of interleukin-2 and its receptor in T cells. Mol Cell Biol. 2005;25:1620-33.

47. Fujii Y, Kumatori A, Nakamura M. SATB1 makes a complex with p300 and represses gp91 (phox) promoter activity. Microbiol Immunol. 2003;47:803-11.

48. Pavan Kumar P, Purbey PK, Sinha CK, Notani D, Limaye A, Jayani RS, Galande S. Phosphorylation of SATB1, a global gene regulator, acts as a molecular switch regulating its transcriptional activity in vivo. Mol Cell. 2006;22:231-43.

49. Han HJ, Russo J, Kohwi Y, Kohwi-Shigematsu T. SATB1 reprogrammes gene expression to promote breast tumour growth and metastasis. Nature. 2008;452:187-93. 
50. Li QQ, Chen ZQ, Xu JD, Cao XX, Chen Q, Liu XP, Xu ZD. Overexpression and involvement of special AT-rich sequence binding protein 1 in multidrug resistance in human breast carcinoma cells. Cancer Sci. 2010;101:80-6.

51. Kohwi-Shigematsu T, Poterlowicz K, Ordinario E, Han HJ, Botchkarev VA, Kohwi Y. Genome organizing function of SATB1 in tumor progression. Semin Cancer Biol. 2013;23:72-9.

52. Rosenbauer F, Wagner K, Kutok JL, Iwasaki H, Le Beau MM, Okuno Y, Akashi K, Fiering S, Tenen DG. Acute myeloid leukemia induced by graded reduction of a lineage-specific transcription factor, PU.1. Nat Genet. 2004;36:624-30.

53. Steidl U, Rosenbauer F, Verhaak RG, Gu X, Ebralidze A, Otu HH, Klippel S, Steidl C, Bruns I, Costa DB, Wagner K, Aivado M, Kobbe G, Valk PJ, Passegue E, Libermann TA, Delwel R, Tenen DG. Essential role of Jun family transcription factors in PU.1 knockdown-induced leukemic stem cells. Nat Genet. 2006; 38:1269-77.

54. Steidl U, Steidl C, Ebralidze A, Chapuy B, Han HJ, Will B, Rosenbauer F, Becker A, Wagner K, Koschmieder S, Kobayashi S, Costa DB, Schulz T, O'Brien KB, Verhaak RG, Delwel R, Haase D, Trumper L, Krauter J, Kohwi-Shigematsu T, Griesinger $\mathrm{F}$, Tenen DG. A distal single nucleotide polymorphism alters long-range regulation of the PU.1 gene in acute myeloid leukemia. J clin Investig. 2007;117:2611-20.

55. Agrelo R, Wutz A. X inactivation and disease. Semin Cell Dev Biol. 2010;21:194-200.

56. Savarese F, Flahndorfer K, Jaenisch R, Busslinger M, Wutz A. Hematopoietic precursor cells transiently reestablish permissiveness for X inactivation. Mol Cell Biol. 2006;26:7167-77.

57. Agrelo R, Souabni A, Novatchkova M, Haslinger C, Leeb M, Komnenovic V, Kishimoto H, Gresh L, Kohwi-Shigematsu T, Kenner L. SATB1 defines the developmental context for gene silencing by Xist in lymphoma and embryonic cells. Dev Cell. 2009;16:507-16.

58. Nechanitzky R, Davila A, Savarese F, Fietze S, Grosschedl R. $S A T B 1$ and $S A T B 2$ are dispensable for $\mathrm{X}$ chromosome inactivation in mice. Dev Cell. 2012;23:866-71.

59. Gyorgy AB, Szemes M, de Juan Romero C, Tarabykin V, Agoston DV. SATB2 interacts with chromatin-remodeling molecules in differentiating cortical neurons. Eur J Neurosci. 2008;27: $865-73$.

60. Dobreva G, Chahrour M, Dautzenberg M, Chirivella L, Kanzler B, Farinas I, Karsenty G, Grosschedl R. SATB2 is a multifunctional determinant of craniofacial patterning and osteoblast differentiation. Cell. 2006;125:971-86.

61. Alcamo EA, Chirivella L, Dautzenberg M, Dobreva G, Farinas I, Grosschedl R, McConnell SK. SATB2 regulates callosal projection neuron identity in the developing cerebral cortex. Neuron. 2008;57:364-77.

62. Zhang J, Tu Q, Grosschedl R, Kim MS, Griffin T, Drissi H, Yang $\mathrm{P}$, Chen J. Roles of SATB2 in osteogenic differentiation and bone regeneration. Tissue Eng Part A. 2011;17:1767-76.
63. Brewer CM, Leek JP, Green AJ, Holloway S, Bonthron DT, Markham AF, FitzPatrick DR. A locus for isolated cleft palate, located on human chromosome 2q32. Am J Hum Genet. 1999;65:387-96.

64. FitzPatrick DR, Carr IM, McLaren L, Leek JP, Wightman P, Williamson K, Gautier P, McGill N, Hayward C, Firth H, Markham AF, Fantes JA, Bonthron DT. Identification of SATB2 as the cleft palate gene on 2q32-q33. Hum Mol Genet. 2003;12:2491-501.

65. Leoyklang P, Suphapeetiporn K, Siriwan P, Desudchit T, Chaowanapanja P, Gahl WA, Shotelersuk V. Heterozygous nonsense mutation SATB2 associated with cleft palate, osteoporosis, and cognitive defects. Hum Mutat. 2007;28:732-8.

66. Herrscher RF, Kaplan MH, Lelsz DL, Das C, Scheuermann R, Tucker PW. The immunoglobulin heavy-chain matrix-associating regions are bound by Bright: a B cell-specific trans-activator that describes a new DNA-binding protein family. Genes Dev. 1995;9:3067-82.

67. Nixon JC, Ferrell S, Miner C, Oldham AL, Hochgeschwender U, Webb CF. Transgenic mice expressing dominant-negative bright exhibit defects in B1 B cells. J Immunol. 2008;181:6913-22.

68. Schmidt C, Kim D, Ippolito GC, Naqvi HR, Probst L, Mathur S, Rosas-Acosta G, Wilson VG, Oldham AL, Poenie M, Webb CF, Tucker PW. Signalling of the BCR is regulated by a lipid raftslocalised transcription factor, Bright. EMBO J. 2009;28:711-24.

69. An G, Miner CA, Nixon JC, Kincade PW, Bryant J, Tucker PW, Webb CF. Loss of Bright/ARID3a function promotes developmental plasticity. Stem Cells. 2010;28:1560-7.

70. Takahashi K, Yamanaka S. Induction of pluripotent stem cells from mouse embryonic and adult fibroblast cultures by defined factors. Cell. 2006;126:663-76.

71. Popowski M, Templeton TD, Lee BK, Rhee C, Li H, Miner C, Dekker JD, Orlanski S, Bergman Y, Iyer VR, Webb CF, Tucker H. Bright/Arid3A acts as a barrier to somatic cell reprogramming through direct regulation of Oct4, Sox2, and Nanog. Stem Cell Rep. 2014;2:26-35.

72. Ngo VN, Davis RE, Lamy L, Yu X, Zhao H, Lenz G, Lam LT, Dave S, Yang L, Powell J, Staudt LM. A loss-of-function RNA interference screen for molecular targets in cancer. Nature. 2006;441:106-10.

73. Peeper DS, Shvarts A, Brummelkamp T, Douma S, Koh EY, Daley GQ, Bernards R. A functional screen identifies hDRIL1 as an oncogene that rescues RAS-induced senescence. Nat Cell Biol. 2002;4:148-53.

74. Shankar M, Nixon JC, Maier S, Workman J, Farris AD, Webb $\mathrm{CF}$. Anti-nuclear antibody production and autoimmunity in transgenic mice that overexpress the transcription factor Bright. J Immunol. 2007;178:2996-3006. 